Article

\title{
Ambition Levels of Nearly Zero Energy Buildings (nZEB) Definitions: An Approach for Cross-Country Comparison
}

\author{
Juan Fernando Garcia * and Lukas Kranzl \\ Institute of Energy Systems and Electrical Drives, Technische Universität Wien, 1040 Wien, Austria; \\ kranzl@eeg.tuwien.ac.at \\ * Correspondence: juanferj_90@hotmail.com
}

Received: 29 August 2018; Accepted: 9 October 2018; Published: 15 October 2018

check for updates

\begin{abstract}
Since buildings account for $40 \%$ of total energy consumption and $36 \%$ of $\mathrm{CO}_{2}$ emissions in the European Union (EU), the directive 2010/31/EU “Energy Performance of Buildings Directive (EPDB)" among other legal provisions concerning the reduction of energy consumption of buildings has been enforced. According to this legislation, all new buildings must be nearly zero energy buildings "nZEB" by 31 December 2020 (public buildings by 31 December 2018). Nonetheless, the assessment of the "high energy performance" of a building is ambiguous and a cross country comparison seems to be intricate since different national building codes and nZEB definitions employ different energy indicators and methods. This paper delves into the question of how do the ambition levels of "nZEB" definitions and the transposition of the Directive 2010/31/EU into national law differ in four selected EU Countries: Austria, Germany, Spain, and England (as part of UK). The energy performance of some exemplary buildings is assessed by means of a simplified MATLAB model that is based on the norm DIN V-18599. The results drawn from this work show how diverse are building codes scopes and national "nZEB" definitions. Only 9 of the 36 studied cases of residential buildings obtain consistently the "nZEB" compliance status in all four selected countries. The results show that climate conditions, energy requirements, primary energy factors, ambition levels, and calculation methodologies lead to the problem of an uneven cross-country comparison. Moreover, primary energy consumption $\left[\mathrm{kWh} / \mathrm{m}^{2} \mathrm{a}\right]$ set as the main quantitative energy indicator by the directive 2010/31/EU might not be the most suitable one for an EU level comparison.
\end{abstract}

Keywords: air-conditioning; building energy performance; climate change; energy demand modelling; domestic hot water; nearly zero energy building; space cooling; space heating

\section{Introduction}

According to the Global status report 2017 prepared by the International Energy Agency (IEA) and coordinated by United Nations Environment Programme for the Global Alliance for Buildings and Construction (GABC), buildings and construction together account for 36\% of global final energy use and $39 \%$ of energy-related carbon dioxide $\left(\mathrm{CO}_{2}\right)$ emissions when upstream power generation is included. For this reason, energy efficiency in buildings has become a key aspect to meet global climate ambitions beyond the 2020 horizon that was set forth in the Paris Agreement and contribute to achieve the Sustainable Development Goal 7 of the 2030 Agenda.

Since buildings account for $40 \%$ of total energy consumption, and $36 \%$ of $\mathrm{CO}_{2}$ emissions in the European Union (EU), two key laws concerning the reduction of energy consumption of buildings have been enforced, the directive 2010/31/EU "Energy Performance of Buildings Directive (EPDB-recast)" and the 2012/27/EU "Energy Efficiency Directive". After a proposal for revision of the Energy 
Efficiency Directive in November 2016, the EU Parliament voted in favour of a binding 35\% energy efficiency target for 2030. The proposal of the European Commission for an amendment of the EPBD-recast (2010/31/EU) delivers new initiatives in several directions, e.g., to ensure the interface of the building stock into the overall energy system by smart devices or to make sure that renovation roadmaps lead towards the long-term goal of a decarbonised building stock. However, the key system of how nZEB definitions should be carried out by the Member States has not been significantly modified [1].

The article 2 of the Energy Performance of Buildings Directive (EPDB) defines a nearly zero energy building as a building that has a "very high energy performance", for which the nearly zero or very low amount of energy required should be covered to a very significant extent by energy from renewable sources, including energy from renewable sources produced on-site or nearby [2]. In the article 9 of the same directive it is stated that Member States (MS) shall ensure that by 31 December 2020, all new buildings are nearly zero-energy buildings and that after 31 December 2018, new buildings occupied and owned by public authorities are nearly zero-energy buildings. Furthermore, all Member States (MS) shall draw up national plans for increasing the number of nearly zero-energy buildings and these shall include a definition of nearly zero-energy buildings, reflecting their national, regional, or local conditions, and including a numerical indicator of primary energy use expressed in [ $\left.\mathrm{kWh} / \mathrm{m}^{2} \mathrm{a}\right]$ [2].

This paper delves into the question of how do the nearly zero energy building "nZEB" definition and the transposition of the Directive 2010/31/EU into national law regarding the procedures to assess the "very high energy performance" on retrofitted residential buildings differ in four selected EU Countries: Austria, England as the selected representative country of the UK, Germany, and Spain.

A recent similar comparison study with different methodology and countries, contrasted existing and nearly zero energy requirements in four countries with a reference office building to analyze the impacts of climate and national regulation on primary energy use. It was found that generally, in Central and North Europe comparison, national input data caused much more difference than the climate [3].

In order to make a cross country comparison of the national building codes and national "nZEB" definitions, a simplified MATLAB model that was based on the calculation procedure of the German norm DIN V 18599 has been developed. The norm DINV 18599 is a summary and improvement of the precedent existing norms (DIN V 4108-6/DIN V 4701-10 und -12, EN 832, ISO 13790). It is important to bear in mind that the calculation procedure and reporting formats of the norms EN ISO 13790 and EN 15603 have been recently revised by the new calculation procedure presented in the norm ISO 52016 and the modular structure for assessing the energy performance of new and existing buildings in a holistic way presented in the norm EN ISO 52000, respectively. The main changes in the calculation procedures include: (a) the revision of the monthly method to calculate the energy needs for heating and cooling. New straightforward formulae were developed for intermittent heating and cooling, and (b) the introduction of a specific hourly method to calculate the hourly energy needs for heating and cooling and the hourly indoor temperature (air, mean radiant, and operative) and latent energy needs (humidification and dehumidification). However, due to the timing of the work carried out in this paper, it was not possible to adapt the methodology to this new standard and we do not expect strong impact on the insights derived from our analysis. Although the dynamic interactions and influence of hourly and daily variations in weather and operation represent an important improvement in the calculation procedure and lead to higher accuracy in the heat balance, a monthly-based calculation procedure suffice to recognize trends in the consistency of nZEB definitions and energy indicators, and hence to compare the ambition level among countries. Furthermore, due to the way in which EN ISO 52000 is considered, it can be inferred that office buildings are the type of buildings that could most directly benefit from the new methodology. This means that the impact of the dynamics in the heat balance are more relevant for this type of buildings than for residential buildings, particularly in regard to hourly and daily operation (solar blinds, thermostats, heating and cooling needs, occupation, heat accumulation). 
For the comparison of the building codes and nZEB definitions, three reference buildings were selected for each of the four countries giving a total of 12 reference buildings. Three cases of energy performance according to different retrofit ambition levels were analysed for each building giving a total of 36 cases. Finally, we checked for each case, whether the building's energy performance matches with the nZEB definition for each considered country.

The selected reference buildings have been chosen mainly from the TABULA EU-building typology database [4], which does not only contain a large set of building types of each national stock, but also typical energy consumption values for each building and statistical data for the supply systems. Two from the 12 buildings have been chosen from the Passive House Database [5].

\subsection{Literature Review}

The initial point of this work has been the review of the regulatory framework. From the global directive 2010/31/EU “Energy Performance of Buildings Directive" down to each country regulation, mandate, decree, building code, and national nZEB plan.

The work of the Concerted Action EPBD (CA-EPBD) contributed strongly to a greater transparency and availability of data on the EU MSs' progress towards nZEBs and their nZEB definitions [6-8]. However, a rigorous and consistent comparison of the real impact of nZEB definitions in different countries has not yet been carried out by the CA-EPBD.

Sartori, et al. (2012) [9] propose a consistent framework for setting Net nZEB definitions, but as they themselves recognize there are possible different definitions in accordance with a country's political targets and specific conditions. Moreover, some research projects have already tried to specify the EPBD's global definition and to define suitable levels for nZEBs in Europe, but, as there are no concrete values in the EPBD definition of nZEB and since there are different climate conditions, primary energy factors, ambition levels, and calculation methodologies, the nZEB definition differs significantly from country to country. In the past, the federation of European Heating, Ventilation and Air Conditioning Associations (REHVA) among others has proposed a detailed definition of nZEB for a consistent national implementation of the EPBD recast arguing that EU MSs might need more guidance in order to set comparable requirements for nZEB's with equal ambition levels $[10,11]$. Even for projects aiming to monitor the nearly zero energy market, like ZEBRA 2020 [12], whose major target is to illustrate collected data about the way of MS and Europe towards nZEB, this unclearness in the 'nearly zero' definition supposed a methodological issue. Quoting one of the project key findings: "A quantitative comparison of national nZEB definitions is complex due to different system boundaries, calculation methodologies, applied factors etc., However, our analysis indicates that a significant share of nZEB definitions does not meet the intention of the EU directive on energy efficient buildings (EPBD) that the energy consumption should be 'nearly zero or very low amount' and the remaining part 'should be covered to a very significant extent by energy from renewable sources'. Thus, a recast EPBD should require clear definitions of terms and thresholds, and gaps should be closed" [11].

The core of this paper is a quantitative comparison by means of the developed MATLAB model for the evaluation of the energy performance of a building, based on the PhD dissertation "Vereinfachungen für de energetische Bewertung von Gebäuden" [13] of Markus Lichtmess and its corresponding excel tool EnerCalC. In this document, the author develops and validates a simplified methodology, which analyses the building envelope according to a single zone model and calculates on the other hand the energy demand according to a multi zone model. This simplified allocation is based on the key assumption that there is a sufficiently good correlation between the building envelope and the energy surface areas (the surface areas of the individual zones).

Several country-specific studies analyse the impact of the building design, thermal envelope parameters, technical systems, calculation methodologies, and local climatic conditions in the energy performance and fulfillment of net and nearly zero energy requirements of reference buildings by means of Case Studies for residential and non-residential buildings [14-19]. Touloupaki, E.; Theodosiou identify the optimal thickness of insulation that is cost-effective to apply in urban multi-family domestic 
buildings in the four climate zones of Greece [15]. Hachem-Vermette, Guarino, La Rocca, \& Cellura, explore a solar mixed-use community and its potential towards achieving net-zero energy status [17]. Cellura, Ciulla, Guarino, \& Longo describe on their paper, the experience of re-design of an existing rural building located in Sicily. A validated model was used for redesign studies aimed towards the achievement of the Net Zero Energy Building target [18]. Zeiler, Gvozdenović, de Bont \& Maassen present a paper on the recently completed Dutch sustainable and nearly zero energy buildings, they concluded that the goal from the Energy Performance of Building Directive now is rarely met [19].

Moreover, at present, there is a considerable number of studies that analyse the differences between existing methodologies, including the floor area considered, internal heat load used in calculations, energy uses included in the calculations, conversion factors, climatic conditions, indoor temperatures, and the inclusion of renewable energy sources in EU countries [3]. Attia et al. present an overview and future challenges of nearly zero energy buildings design in seven Southern European countries, the study analyses the present situation and provides an overview on future prospects for nZEB in Southern Europe, finding that most Southern European countries are poorly prepared for nZEB implementation and especially to the challenge/opportunity of retrofitting existing buildings [20]. Similarly, Guarino et al., propose a simplified methodology to optimize solar energy gains at district level in the Mediterranean area toward the achievement of the net-zero energy district target, to be applicable as well in similar hot climates [21].

D'Agostino et.al provide an overview of the status of implementation of nZEBs in Europe with a focus on retrofit and show that diversified approaches are in place for the improvement of existing buildings energy performance, involving technical, economic, and financial aspects, but find that a comprehensive retrofit implementation is still distant at EU level [22]. Beyond the EU, Yahya Wisam Al-Saeed and Abdullahi Ahmed review the current established nZEB standards and definitions in the hot and warm climate of some European countries and investigate the potential reductions in primary energy consumption through design strategies for nZEB buildings in the MENA (Middle East and North Africa) region [23].

This paper starts by considering the fact that setting a suitable EU definition for nZEB is a challenging task, as referred by Hermelink et al., 2013 [24]. However, it goes beyond and intends to compare in a qualitative and a quantitative way the nZEB definition and nearly zero energy requirements from the selected countries and determine whether there is a consistent assessment of the nZEB compliance under the conditions referred in the Section 2.1 "Building selection and assessment criteria".

\subsection{Countries Building Code Description}

In this chapter, the different national building codes and nZEB national plans are examined. Key aspects and energy requirements from each country's building code are presented and described. In the last section, most remarkable differences between building codes are discussed and summarized.

Building codes, standards, and the state of nZEB definitions are subject to continuous changes. The description of the following section refers mainly to the state of early-2017 when the quantitative comparison among selected countries was conducted using the MATLAB model. However, comments on most relevant changes occurred afterwards are given by the end of each section.

\subsubsection{Austria (OIB-330.6-009/2015)}

Formal "nZEB" definitions, as well as qualitative and quantitative energy requirements, are stated for both new construction and existing buildings (large renovation) in the OIB guideline 6: 'Energieeinsparung und Wärmeschutz' [25-27]. A nearly zero energy building under the Austrian scope is that building that complies with the energy requirements stated in the above-mentioned guideline for the year 2020. Four main energy indicators are settled in the document: (a) Energy need for space heating "Heizwärmebedarf" in $\left[\mathrm{kWh} / \mathrm{m}^{2} \mathrm{a}\right]$, (b) Primary energy demand in $\left[\mathrm{kWh} / \mathrm{m}^{2} \mathrm{a}\right]$, (c) Carbon dioxide emission in $\left[\mathrm{kg} / \mathrm{m}^{2} \mathrm{a}\right]$, and (d) Total energy efficiency factor fGEE [-]. This last 
indicator, the total energy efficiency factor ' $\mathrm{fGEE}$ ' is a comparative value, which results from the established reference value of the energy demand of an object with the listed requirements from the year 2007. The resulting quotient is the total energy efficiency factor. A value of less than 1 means an improvement on the energy quality respect to the specified new construction standard in the 2007 calculation year.

The nZEB status is achieved when the (b) Primary energy demand, and the (c) Carbon dioxide emission requirements are fulfilled and:

- Alternative 1: Either the energy need for heating "HWB-Heizwärmebedarf" requirement and a minimum efficiency of the building technical installations "HTEB-Heiztechnikenergiebedarf" are fulfilled.

- Alternative 2: Either the energy need for heating "HWB- Heizwärmebedarf" requirement and the fGEE requirement are fulfilled.

Intermediate targets for the years 2014, and the following 2016 and 2018 are also included as required by the EPBD directive 31 in its article 9.3.b. Requirements regarding the minimum share of renewables are clearly defined in the Section 4.3 of the guideline.

\subsubsection{Germany (EnEV 2016) (Expected GEG 2018)}

The nZEB definition in Germany is to be formally settled and implemented by the federal government in the Energy Conservation Regulation (EnEV 2016). Nonetheless, an expected definition in line with the KfW Efficiency house is already foreseen in the nZEB national plan of 2013. For new buildings the ambition level points to the label KfW 40 and for refurbishments points to the label $\mathrm{KfW} 55$ and 70. The numbers indicate the amount of annual primary energy consumption in relation (\%) to a comparable new building (reference building), according to the requirements of the Energy Conservation Regulation in force. An Efficiency House 40, for example, does not use more than $40 \%$ of the annual primary energy consumption of the corresponding reference building. The main energy requirement might be therefore only the primary energy consumption, as described above (KfW label). The Energy Saving Ordinance (EnEV) includes additional requirements regarding the mean specific heat transmission losses of the building envelope, thermal bridges, air tightness, and the summer heat protection (in order to avoid overheating).

Contrary to the other analysed country scopes, the German code does not allow for a maximum energy need for space heating, but it goes the other way around by limiting the specific heat transmission losses of the building envelope for residential buildings to the maximum values presented in Table 2 from Annex 1 of the building code, and limiting the U-Values for non-residential buildings to the maximum values presented in Table 1 from Annex 2 of the building code.

A minimum share of renewables is also designated taking into account the considerations of the EEWärmeG part 2 articles 4 and 5 for new and existing non-residential buildings undergoing deep renovations, respectively, and the alternative measures presented in the article 7.

[Stand 2018: As foreseen, the nZEB definition for public buildings that is used by government institutions has been proposed in line with the KfW "Effizienzhaus 55-Standard" in the draft of the "GebäudeEnergieGesetz 2018" expected to be enforced in 2018, a formal nZEB definition for new residential buildings is expected to come out before 2021].

\subsubsection{Spain (Documento Basico de Ahorro de Energia—DBHE)—Royal Decree 235/2013}

Royal decree 235/2013 approving the basic procedure for certifying the energy performance of buildings also includes an obligation for all new buildings built after 31 December 2020 to be nearly zero-energy buildings and all new buildings for which construction starts after 31 December 2018 that will be occupied and owned by public authorities also to be nearly zero-energy buildings is the designated legal document for the transposition of the directive 2010/31/EU into national law. 
The Spanish national nZEB plan is arranged in two phases. The first one consists on the set of intermediate targets for new construction from 2015 to promote the achieving of the 2020 targets. The second phase consists on the regulatory definition of nearly zero energy buildings. A formal nZEB definition is to be addressed in the new basic Energy Saving Basic Document DB-HE 2016/2017.

Within the 2013 approved regulation and already in force, two global indicators (plus a possible subsequent third) and some additional specific construction and technical system requirements are set to be used as a basis for defining a nearly zero energy building. The mentioned requirements (and the possible third one) are: (a) Primary energy use (non-renewable) in $\left[\mathrm{kWh} / \mathrm{m}^{2} \mathrm{a}\right]$, (b) Energy demand for heating and cooling in $\left[\mathrm{kWh} / \mathrm{m}^{2} \mathrm{a}\right]$, and (c) Building $\mathrm{CO}_{2}$ Emissions (possible subsequent indicator).

The Spanish code specifies other requirements, which include the maximum transmittance of elements of the thermal envelope and other elements separating different user units, minimum energy efficiency of heating systems and lighting, maximum installed power in the building for lighting purposes, minimum energy contribution from renewable sources for the supply of domestic hot water system, and for electrical uses in the building.

Six winter climate zones $(\alpha$, A, B, C, D, E) SCI and four summer climate zones $(1,2,3,4)$ SCV have been defined in the annex B.3 of the document "Documento descriptivo climas de referencia" [28] of the diversification ministry. These zones are important because energy performance requirements depend on the building location.

According to the national nZEB plan, for existing construction, in work affecting more than $25 \%$ of the building envelope or in work where the building's characteristic use is changed, the requirement is that the building should be at least compliant with the energy demand needs established in 2006 for new buildings (DBHE 2006).

[Stand 2018: The nZEB definition for new public, residential, and non-residential buildings has been released in the building code DBHE according to the order FOM/588/2017 of 15 June 2017. Likewise, a preliminary document with the basis for the new Basic Document DB-HE 2018 has been released. The envisaged changes include the consideration of the total and non-renewable primary energy consumption in $\left[\mathrm{kWh} / \mathrm{m}^{2} \mathrm{a}\right]$, more detailed requirements in the use of renewables (i.e., Minimum contribution of energy from renewable sources, water heating of indoor swimming pools and conditioning of open spaces permanently) and the consideration of additional requirements, such as the Global thermal transmittance (K) and Solar control. The new Basic Document DB-HE 2018 is however a preliminary work and has no regulatory character].

\subsubsection{England (Conservation of Fuel and Power: Approved Document L)—National nZEB Plan}

As described in the UK nZEB national plan, the UK Government has already a target for all new domestic buildings in England to be "zero carbon" from 2016 and an ambition for all new non-domestic buildings in England to be zero carbon from 2019 (2018 for new public-sector buildings). Similar standards and targets for zero carbon dwellings and buildings with some time shift are proposed by North Ireland and Scotland. However, the focus of this study remains in England as a representative country of the UK.

The "zero carbon" definition has been developed by the partnership between the UK Government and the Zero Carbon Hub non-profit organization and is intended to meet the nearly zero energy building definition. No formal definition is given for existing buildings.

Under the interpretation of the UK Government the word "should" signify an aspiration rather than an obligation. That is why they do not include a minimum share of renewables. However, the "zero carbon" definition together with the local policies are supposed to encourage the use of on-site renewables and heat networks that could be connected in the future with renewable heat sources. Another argument against the inclusion of a minimum share of renewables is the fact that low carbon technologies have still an important role to play in the aims of the directive mainly because high energy performance can be achieved at a lower cost. 
Part L of the building regulations in England contains the changes made by the UK government to improve energy standards. There are two main quantitative energy requirements in the Part L1A for new dwellings (residential buildings): (a) Target $\mathrm{CO}_{2}$ Emission rate TER $\left[\mathrm{kg} \mathrm{CO}_{2} / \mathrm{m}^{2} \mathrm{a}\right.$, and (b) Target fabric energy efficiency TFEE rate $\left[\mathrm{kWh} / \mathrm{m}^{2} \mathrm{a}\right]$. In the same way, one main quantitative energy requirement in the Part L2A for new buildings other than dwellings (non-residential and public buildings): (a) Target $\mathrm{CO}_{2}$ Emission rate TER $\left[\mathrm{kg} \mathrm{CO} / \mathrm{m}^{2} \mathrm{a}\right]$.

Both of them TER and TFEE indicators are relative maximum reference values that are calculated for a notional building (set out in the Appendix R of SAP 2012 for dwellings and in the National Calculation Methodology NCM modelling guide for buildings other than dwellings) with the same size and shape of the actual building. In every case, the Dwelling $\mathrm{CO}_{2}$ emission rate (DER)/Building $\mathrm{CO}_{2}$ emission rate (BER) shall be less or equal to the Target $\mathrm{CO}_{2}$ emission rate (TER), and the dwelling fabric energy efficiency (DFEE) shall be less or equal to the Target fabric energy efficiency TFEE.

Additional demonstrating compliance criteria are presented in the Building Regulations part L. These include the specification of the performance of building elements and building fixed services in order to achieve reasonable overall standards of energy efficiency. This is, however, more guidance than a mandate [29].

\subsubsection{Summary}

Every country's building code points in the same direction to the improvement of both the building thermal envelope and the energy efficiency by means of high efficiency technical systems and low carbon technologies, together with the use of renewable energy sources, yet there are some remarkable differences on their approaches. Most significant differences between the four analysed countries are:

- Only the Austrian norm includes the auxiliary energy and the household electricity demand in the calculation procedure. The German code includes the auxiliary energy for non-residential buildings under certain conditions.

- Unlike the other countries' building codes, Germany does not have a quantitative energy requirement for the energy need for heating and cooling. Instead, the code limits the specific heat transmission losses through $\mathrm{H}_{\mathrm{T}}{ }^{\prime}$ in residential buildings.

- German code does not consider the end use: lighting for the calculation of the primary energy in residential buildings.

- Austria is the only country among the considered cases that already has set an nZEB definition for existing buildings that are subject to retrofit/large renovation. This means differentiated quantitative requirements for retrofitted buildings in order to achieve the nZEB status.

- Although England's building code defines the requisite for the use of at least one choice of renewable energies, it does not specify formal quantitative requirements.

- Due to its location and variety of climate conditions within the country, Spain defines differentiated energy requirements according to the climate zone. A correction factor depending on the size (floor area) of the building is used for the calculation of the requirements in energy need for heating and cooling and primary energy consumption.

\section{Methodology}

This chapter describes the methodology applied in this paper in order to carry out a qualitative as well as a quantitative cross-country comparison of the energy indicators stated in the respective building codes and the national nZEB definition.

The key approach of this work is:

- Selection of three reference buildings from each of the selected countries that represents the respective national building stock.

- Assumption of three ambition levels (Energy performance) for these reference buildings. 
- Assessment of the compliance with nZEB definition of the own and other countries under certain assumptions.

- Derivation of conclusions.

\subsection{Building Selection and Assessment Criteria}

Four countries were selected for the cross-country comparison: Austria, England, Germany, and Spain. For each country, three residential buildings were selected trying to maintain a resemblance in the construction year and construction type in each case between countries. From the 12 buildings, data of 10 of them was obtained from the TABULA EU-building typology database [4] and the data of the other two, namely the single-family house in Spain and the multi-family house in England, was obtained from the Passive House Project Database [5]. The motivation for the selection of these buildings lies first on the interest to involve and compare ambition level differences and whether the passive house standard present/imply differences in the energy performance. Second, the fact that there was limited data for apartment blocks in Spain and England by the time of the building selection.

Each one of the 12 buildings has been modelled under three cases following this scheme:

- Case 1-Original building (no refurbishment): as built.

- Case 2-Building subject to usual retrofit measures (usual refurbishment): improvements on the thermal envelope as well as on the technical systems.

- Case 3-Building subject to an ambitious retrofit aiming to obtain nZEB status (advanced refurbishment).

Additionally, the reference building case "Ref" is presented and it corresponds to the building equipped with the technical installations and constructive elements to comply with the minimum energy requirements according to the respective country's building code.

Note that, in some cases, depending mostly on the year of construction, the parameters (particularly the U-Values) of the case 1 "original building" can be worse (higher) than the ones of the reference case "Ref".

The most important characteristics of selected buildings are shown in Table 1 . This includes the net conditioned volume, the number of levels, the conditioned reference area (NGF), the total surface of the building envelope (sum of the surface area of each building element that is part of the building thermal envelope) and the compactness defined as the ratio between the building envelope surface and the conditioned volume.

Table 1. Selected reference buildings by country and main characteristics.

\begin{tabular}{|c|c|c|c|c|c|c|}
\hline Country & $\begin{array}{l}\text { Building } \\
\text { Type }\end{array}$ & $\begin{array}{l}\text { Net Volume } \\
{\left[\mathrm{m}^{3}\right]}\end{array}$ & $\begin{array}{l}\text { Number of } \\
\text { Levels }\end{array}$ & $\begin{array}{c}\text { Conditioned } \\
\text { Reference Area }\left[\mathrm{m}^{2}\right]\end{array}$ & $\begin{array}{l}\text { Total Surface } \\
\text { Area A }\left[\mathrm{m}^{2}\right]\end{array}$ & $\begin{array}{c}\text { Compactness } \\
\text { (A/Ve) }\end{array}$ \\
\hline \multirow{2}{*}{ Austria } & SFH & 632.9 & 2 & 153.4 & 480 & 1.32 \\
\hline & $\mathrm{AB}$ & 3511.6 & 5 & 906 & 1764 & 1.99 \\
\hline Germany & SFH & 827.1 & 2 & 186.8 & 509.3 & 1.62 \\
\hline \multirow{3}{*}{ Spain } & SFH & 406.2 & 2 & 119.2 & 332 & 1.22 \\
\hline & $\mathrm{MFH}$ & 3741 & 4 & 1419 & 1797 & 2.08 \\
\hline & SFH PHS & 2025 & 3 & 262 & 540 & 3.75 \\
\hline England & SFH & 358.9 & 2 & 149.4 & 378.1 & 0.95 \\
\hline
\end{tabular}

SFH = Single-family house; MFH = Multi-family house; $\mathrm{AB}=$ Apartment block; $\mathrm{PHS}$ = Passive house.

The building envelope characteristics, namely the U-values for each case of each building are presented in Table 2. 
Table 2. Building envelope characteristics: U-Values.

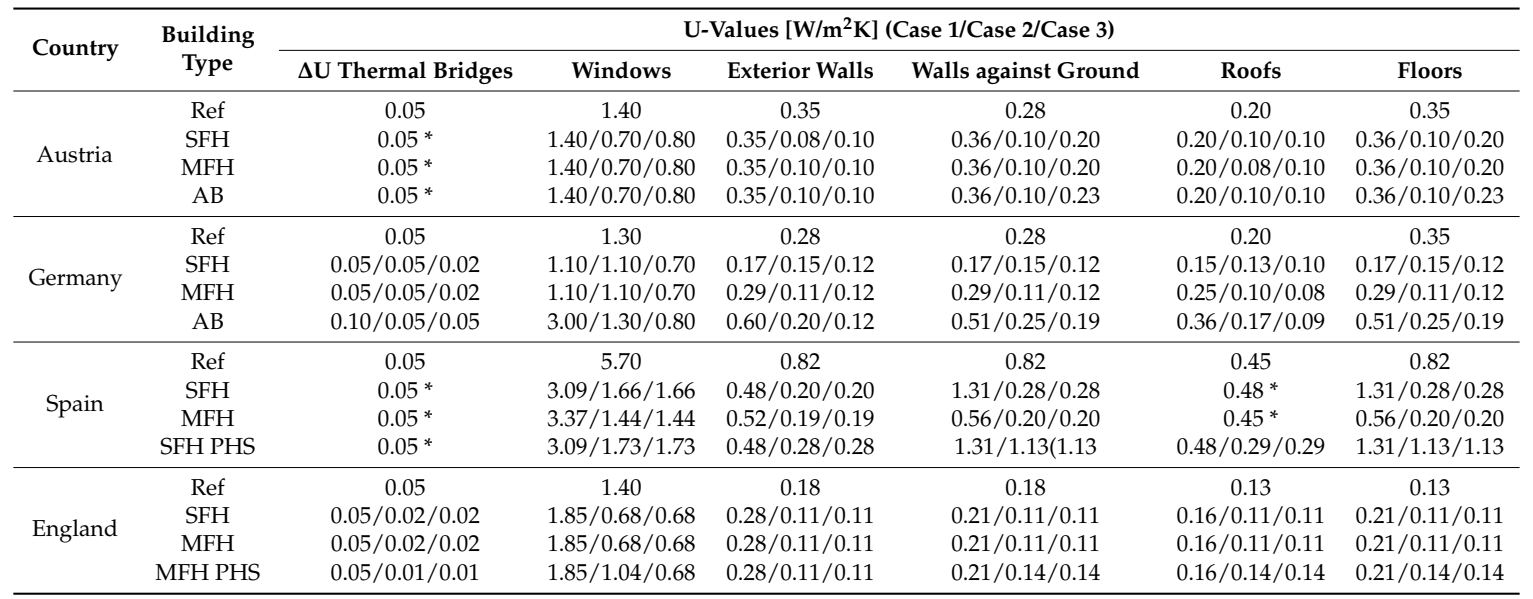

* Same value for all three cases (case1/case2/case3). SFH = Single-family house; MFH = Multi-family house; $\mathrm{AB}=$ Apartment block; PHS = Passive house.

Table 3 contains the most relevant parameters regarding the building technical systems for each case of each building.

Table 3. Building technical installations (Space heating, domestic hot water (DHW), and cooling).

\begin{tabular}{|c|c|c|c|c|c|c|c|}
\hline \multirow{3}{*}{ Country } & \multirow{3}{*}{$\begin{array}{l}\text { Building } \\
\text { Type }\end{array}$} & \multicolumn{6}{|c|}{ Technical System (Case 1/Case 2/Case 3) } \\
\hline & & \multicolumn{2}{|c|}{ Space Heating } & \multicolumn{2}{|c|}{ Domestic Hot Water (DHW) } & \multicolumn{2}{|c|}{ Cooling } \\
\hline & & Energy Carrier & EEC & Energy Carrier & EEC & $\begin{array}{l}\text { Energy } \\
\text { Carrier }\end{array}$ & EER \\
\hline \multirow{4}{*}{ Austria } & Ref & Oil & 1.12 & Oil & 1.03 & - & \\
\hline & SFH & Oil/Oil/Wood pellets & $1.12 / 1.12 / 1.34$ & Oil/Oil/Wood pellets & $1.03 / 1.03 / 1.34$ & & \\
\hline & Ref & Oil & 1.12 & Oil & 1.03 & & \\
\hline & $\mathrm{AB}$ & Gas/Gas/DH & $1.12 / 1.12 / 1.02$ & Gas/Gas/DH & $0.20 / 0.08 .1 .02$ & & \\
\hline \multirow{5}{*}{ Germany } & Ref & Oil & 1.08 & Oil & 1.23 & & \\
\hline & SFH & Gas/Gas/Wood pellets & $1.08 / 1.08 / 1.37$ & Gas/Gas/Wood pellets & $1.23 / 1.23 / 1.63$ & & \\
\hline & Ref & Oil & 1.08 & Oil & 1.06 & & \\
\hline & MFH & Gas * & $1.18 *$ & Gas * & $1.06 *$ & & \\
\hline & Ref & Oil & 1.23 & Oil & 1.20 & & \\
\hline \multirow{3}{*}{ Spain } & MFH & Gas/Gas/Wood pelets & $1.15 / 1.00 / 1.05$ & Gas * & $1.43^{*}$ & Electricity & $2.33 / 3.80 / 3.80$ \\
\hline & Ref & Gas & 1.09 & Gas & 1.09 & Electricity & 2.00 \\
\hline & SFH PHS & $\begin{array}{l}\text { Gas/ Electricity ** } \\
\text { /Electricity ** }\end{array}$ & $1.00 / 0.50 / 0.38$ & $\begin{array}{l}\text { Gas / Electricity ** } \\
\text { /Electricity ** }\end{array}$ & $1.43 / 0.50 / 0.38$ & Electricity & $2.33^{*}$ \\
\hline \multirow{6}{*}{ England } & Ref & Gas & 1.19 & Gas & 1.19 & & \\
\hline & SFH & Gas/ Gas/ Electricity ^ & $1.19 / 1.19 / 1.40$ & Gas/ Gas/ Electricity ^ & $1.19 / 1.19 / 1.00$ & & \\
\hline & Ref & Gas & 1.19 & Gas & 1.19 & & \\
\hline & MFH & Gas * & 1.19 * & Gas * & $1.19 *$ & & \\
\hline & Ref & Gas & 1.19 & Gas & 1.19 & & \\
\hline & MFH PHS & Electricity *, & $5.26^{*}$ & Electricity *, & $0.53 *$ & & \\
\hline
\end{tabular}

* Same value for all three cases (case 1/case 2/case 3); ^ Heat Pumps; Cooling unit-Air, Cold water 14/18 Std. $\mathrm{SFH}=$ Single-family house; MFH = Multi-family house; $\mathrm{AB}=$ Apartment block; PHS = Passive house; $\mathrm{EEC}=$ Energy Expenditure Coefficient; EER = Energy Efficiency Rate.

The specific criteria for the assessment of the building energy performance are the main quantitative energy indicators from each country's building code. In principle and while considering that there is not a formal nZEB definition for existing residential buildings in every country, some general and country specific assumptions must be done: 
- General assumptions and considerations:

1. Since the developed MATLAB BEP model is based on the German norm DIN V 18599, the boundary conditions of use are the same for all buildings in all countries and correspond to those in the part 10 of the mentioned norm. These include for example: the temperature set-points $\left(20^{\circ} \mathrm{C}\right.$-heating, $25^{\circ} \mathrm{C}$-cooling); technical systems daily operation time (ventilation: $24 \mathrm{~h} /$ day, heating system: $17 \mathrm{~h} /$ day); and domestic hot water reference values (single-family house: $11\left[\mathrm{kWh} / \mathrm{m}^{2} \mathrm{a}\right]$, multi-family house $15\left[\mathrm{kWh} / \mathrm{m}^{2} \mathrm{a}\right]$ ). This assumption has by all means a certain impact in the accuracy of the model, since the operation and user behavior issues relative to each country are not fully addressed. However, the difference between selected and country specific boundary conditions is minor for the selected countries.

2. Each building is assessed using the primary energy factor of each of the other countries. That means for example that in the case of a German building, when assessed under the Austrian scope, Austrian Primary energy and $\mathrm{CO}_{2}$ Emission factors are used.

- Assumptions and considerations for the assessment under Austria's scope:

1. Austria is the only country that already by January 2016 had a formal nZEB definition for both new and retrofitted buildings, so the assessment of the buildings under the Austrian scope is done according to the requirements for residential existing buildings (subject to large renovation).

2. Austria is the only country that includes the household overall electricity demand, i.e., including appliances etc., in the calculation procedure. In order to have an even comparison between countries, the maximum reference value for the primary energy in Austria has been modified by subtracting a default value that represents this household electricity demand. A default value is given in the OIB guideline 6 of 2011 as the $50 \%$ of the internal heat sources from persons and appliances.

- Assumptions and considerations for the assessment under England's scope:

1. In the case of England, the nZEB definition goes in line with an already existing initiative for new residential buildings from 2016, called "zero carbon hub", and hence the buildings under the English scope are assessed following the requirements of the document part L1A for new residential buildings.

- Assumptions and considerations for the assessment under Germany's scope:

1. Germany does not have a formal nZEB definition for buildings other than public buildings that are used by the government. The formal nZEB definition for new residential buildings is expected before 2021. The assessment under the German scope is therefore done assuming that requirements for residential buildings (subject to large renovation) are in line with the label KfW 55. The number 55 means that the building does not use more than $55 \%$ of the annual primary energy consumption of the corresponding reference building stated according to the requirements of the Energy conservation regulation EnEV.

- Assumptions and considerations for the assessment under Spain's scope:

1. Spain does not have a formal nZEB definition for retrofitted buildings (subject to large renovations). The nZEB definition that was presented in the updated Spanish building code DBHE under the order FOM/588/2017 of June 2017 refers to new residential and non-residential buildings. The assessment under the Spanish scope is therefore done considering the numeral 3 "Intermediate targets as of 2015 for improving the energy performance of buildings" and specifically the Section 3.1.2: "Updating standards for work 
in existing buildings" of the Spanish national nZEB plan. There is stated that in work affecting more than $25 \%$ of the envelope or in work where the building's characteristic use is changed, the requirement is that the building should be at least compliant with the energy demand needs established in the previous version of the building code DBHE (2006) for new buildings.

2. Due to the significant climate variation and different climate zones within the country, classified from A to E depending on the winter severity, being the zone $\mathrm{E}$ the one with the most severe winter, an assumption that is needed so that all buildings form the other three countries (Austria, Germany, and England) are assumed to be located in the climate zone E.

\subsection{Model Description}

The developed MATLAB BEP model is a simplified model that is based on the calculation procedure presented on the German norm DIN V 18599 and the validated simplifications introduced by Markus Lichtmess [13] It is a multi-zone model (up to 7 zones) intended for the calculation of the energy need, final- and primary energy for heating, cooling, lighting, and domestic hot water. A zone in this context describes an internal environment with assumed sufficiently uniform thermal conditions to enable a thermal balance calculation. A multi-zone model therefore refers to a model in which the building is divided into zones and the thermal balance calculation is carried out in each one of them (thermal coupling between zones might also be considered) to obtain the energy need for heating and cooling.

The strongest simplifications of the model befall on the technical installations. Among the assumptions and limitations of the model are:

- Use of tabled values for the generation-expenditure factors and auxiliary energy according to the norm DIN 4701-10.

- Use of tabled values for the distribution losses of the heating and domestic hot water systems. (Losses can be also set as a user input for the model).

- Modelling of simple ventilation systems with constant volume and heat recovery up to $75 \%$. The energy need for the heat/cold register and related technical losses of the ventilation system are not considered.

- Simplified Solar-thermal system with pre-selected collector surface.

The BEP model calculation procedure consists of nine fundamental steps described, as follows:

1. Data Collection/Setting of boundary conditions.

2. Building thermal envelope definition and zoning procedure.

3. Monthly balance procedure for the calculation of the energy use and final energy for lighting.

4. Monthly balance procedure for the calculation of the energy need for heating/cooling.

5. Calculation of the energy need for domestic hot water.

6. Calculation of the control and emission, distribution and storage energy losses for heating, cooling and domestic hot water systems.

7. Distribution of the calculated energy demand by energy carrier.

8. Calculation of the final energy demand by means of the generation-expenditure factor.

9. Calculation of the primary energy and $\mathrm{CO}_{2}$ Emissions by means of the primary energy and $\mathrm{CO}_{2}$ emission factors.

\subsection{Model Validation}

The developed MATLAB BEP model has been validated using the EnerCalC excel-tool [30] version 4.43.110 and the available results from the TABULA EU-building typology database [4]. The results of three well documented buildings have been compared to the results that were obtained by the own developed MATLAB model. 
The first building corresponds to the basic example of the EnerCalC excel-tool [30] and it is a non-residential building (office building) with seven zones. The validation results for this building are presented in Table 4 (Energy need) and Table 5 (Primary energy). The second considered building is built under passive house concept "Kleehäuser im Freiburger Vauban-Viertel" also presented as a study case by the EnOB: 'Forschung für Energieoptimiertes Bauen [31]. The validation results for this building are presented in Table 6 (Energy need) and Table 7 (Primary energy). These two buildings are located in Germany, thus the DINV 18599 reference climate is used for both cases. The third building is the Single-Family House for Austria (AT_N_SFH_08 according to the TABULA EU-building typology database terminology) subject to usual retrofit which corresponds to the case 2 . For this building, the MATLAB model results were compared with both EnerCalC excel-tool [30] results and the available results from the TABULA EU-building typology database [4]. The Austrian reference climate designated in the Ö-Norm 8110-5 is used in this case [32]. The validation results for this building are presented in Table 8 (Energy need) and Table 9 (Primary energy).

Table 4. Validation results energy need-office building 1.

\begin{tabular}{cccc}
\hline \multirow{2}{*}{ Tool } & \multicolumn{3}{c}{ End Use } \\
\cline { 2 - 4 } & Heating & Cooling & Domestic Hot Water (DHW) \\
\hline MATLAB (Own Model) $\left[\mathrm{kWh} / \mathrm{m}^{2} \mathrm{a}\right]$ & 60.23 & 22.08 & 4.82 \\
EnerCalc 2013 [kWh/m $\left.\mathrm{m}^{2} \mathrm{a}\right]$ & 59.50 & 23.00 & 4.80 \\
Absolute error [kWh/m $\left.\mathrm{m}^{2} \mathrm{a}\right]$ & 0.73 & 0.92 & 0.02 \\
Relative error $[\%]$ & $1.22 \%$ & $3.99 \%$ & $0.49 \%$ \\
\hline
\end{tabular}

Table 5. Validation results primary energy—office building 1.

\begin{tabular}{|c|c|c|c|c|c|}
\hline \multirow[b]{2}{*}{ Tool } & \multicolumn{5}{|c|}{ End Use } \\
\hline & Heating & Cooling & $\begin{array}{l}\text { Domestic Hot } \\
\text { Water (DHW) }\end{array}$ & Lighting & $\begin{array}{c}\text { Ventilation } \\
\text { (Electricity for Fans) }\end{array}$ \\
\hline MATLAB (Own Model) [kWh/m²a] & 127.50 & 18.69 & 9.79 & 45.72 & 33.75 \\
\hline EnerCalc $2013\left[\mathrm{kWh} / \mathrm{m}^{2} \mathrm{a}\right]$ & 118.50 & 19.30 & 9.20 & 48.50 & 28.80 \\
\hline Absolute error $\left[\mathrm{kWh} / \mathrm{m}^{2} \mathrm{a}\right]$ & 9.00 & 0.61 & 0.59 & 2.78 & 4.95 \\
\hline Relative error $[\%]$ & $7.59 \%$ & $3.15 \%$ & $6.47 \%$ & $5.72 \%$ & $17.80 \%$ \\
\hline
\end{tabular}

Table 6. Validation results energy need-Kleehäuser im Freiburger Vauban-Viertel.

\begin{tabular}{cccc}
\hline \multirow{2}{*}{ Tool } & \multicolumn{3}{c}{ End Use } \\
\cline { 2 - 4 } & Heating & Cooling & Domestic Hot Water (DHW) \\
\hline MATLAB (Own Model) $\left[\mathrm{kWh} /{ }^{2} \mathrm{a}\right]$ & 28.50 & - & 15.00 \\
EnerCalc $2013\left[\mathrm{kWh} / \mathrm{m}^{2} \mathrm{a}\right]$ & 27.00 & - & 16.10 \\
Absolute error $\left[\mathrm{kWh} / \mathrm{m}^{2} \mathrm{a}\right]$ & 1.50 & - & 1.10 \\
Relative error $[\%]$ & $5.54 \%$ & - & $6.83 \%$ \\
\hline
\end{tabular}

Table 7. Validation results primary energy-Kleehäuser im Freiburger Vauban-Viertel.

\begin{tabular}{|c|c|c|c|c|c|}
\hline \multirow[b]{2}{*}{ Tool } & \multicolumn{5}{|c|}{ End Use } \\
\hline & Heating & Cooling & $\begin{array}{l}\text { Domestic Hot } \\
\text { Water (DHW) }\end{array}$ & Lighting & $\begin{array}{c}\text { Ventilation } \\
\text { (Electricity for Fans) }\end{array}$ \\
\hline MATLAB (Own Model) [kWh/m²a] & 63.59 & - & 28.35 & 47.56 & 15.50 \\
\hline EnerCalc $2013\left[\mathrm{kWh} / \mathrm{m}^{2} \mathrm{a}\right]$ & 57.50 & - & 26.40 & 47.80 & 15.30 \\
\hline Absolute error $\left[\mathrm{kWh} / \mathrm{m}^{2} \mathrm{a}\right]$ & 6.09 & - & 1.95 & 0.24 & 0.20 \\
\hline Relative error [\%] & $10.60 \%$ & - & $7.40 \%$ & $0.50 \%$ & $1.30 \%$ \\
\hline
\end{tabular}


Table 8. Validation results energy need—single-family house for Austria.

\begin{tabular}{cccc}
\hline \multirow{2}{*}{ Tool } & \multicolumn{3}{c}{ End Use } \\
\cline { 2 - 4 } & Heating & Cooling & Domestic Hot Water (DHW) \\
\hline MATLAB (Own Model) $\left[\mathrm{kWh} / \mathrm{m}^{2} \mathrm{a}\right]$ & 45.60 & 9.45 & 10.97 \\
EnerCalc 2013 [kWh/m $\left./ \mathrm{m}^{2} \mathrm{a}\right]$ & 42.40 & 11.80 & 12.00 \\
Relative error Enercalc [\%] & $7.55 \%$ & $19.95 \%$ & $8.57 \%$ \\
TABULA Webtool [kWh/m $\left./ \mathrm{m}^{2} \mathrm{a}\right]$ & 52.00 & - & 10.00 \\
Relative error TABULA $[\%]$ & $12.30 \%$ & - & $9.71 \%$ \\
\hline
\end{tabular}

Table 9. Validation results primary energy—single-family house for Austria.

\begin{tabular}{cccccc}
\hline \multirow{2}{*}{ Tool } & \multicolumn{5}{c}{ End Use } \\
\cline { 2 - 6 } & Heating & Cooling & $\begin{array}{c}\text { Domestic Hot } \\
\text { Water (DHW) }\end{array}$ & Lighting & $\begin{array}{c}\text { Ventilation } \\
\text { (Electricity for Fans) }\end{array}$ \\
\hline MATLAB (Own Model) $\left[\mathrm{kWh} / \mathrm{m}^{2} \mathrm{a}\right]$ & 71.83 & 9.98 & 33.19 & 13.60 & - \\
EnerCalc 2013 [kWh/m $\left./ \mathrm{m}^{2} \mathrm{a}\right]$ & 73.50 & 10.70 & 33.30 & 15.30 & - \\
Absolute error $\left[\mathrm{kWh} / \mathrm{m}^{2} \mathrm{a}\right]$ & $2.27 \%$ & $6.73 \%$ & $0.33 \%$ & $11.13 \%$ & - \\
Relative error Enercalc $[\%]$ & 1.67 & 0.72 & 0.11 & 1.70 & - \\
\hline
\end{tabular}

It is to be noted that the results from this last building validation differ from the actual results presented on the results section. This is because different conditions were taken for the validation:

- Use of different primary energy and $\mathrm{CO}_{2}$ factors than those stated by norm in the Austrian OIB Guideline 6 (TABULA EU-building typology database conversion factors are used since these are predefined and not editable by the user and results are calculated based on them):

- Primary energy factor Gas: $1.23\left[\mathrm{kWh}_{\text {prim }} / \mathrm{kWh}_{\text {final }}\right]$

- $\mathrm{CO}_{2}$ Emissions factor Gas: $311\left[\mathrm{gCO}_{2} / \mathrm{kWh}_{\text {final }}\right]$

- Primary energy factor Electricity (non-renewable): $2.15\left[\mathrm{kWh}\right.$ prim $\left./ \mathrm{kWh}_{\text {final }}\right]$

- $\mathrm{CO}_{2}$ Emissions factor Electricity: $417\left[\mathrm{gCO}_{2} / \mathrm{kWh}_{\text {final }}\right]$

- Consideration of the energy consumption for cooling (which is not considered in the Austrian building code for the nZEB definition).

- Use of different lighting technology. For the validation Fluorescent lamps with electronic ballast are used instead of LED lamps).

- Use of fans for ventilation and hence inclusion of electricity for this end-use component.

\section{Results}

In order to give a more sensitive approach on the compliance or non-compliance of the nZEB definition, a numerical indicator together with a color scale has been calculated for each nZEB indicator in each scenario of each building. This indicator gives an idea of to which extent the normalized result regarding the maximum reference value complies with each country's nZEB definition.

A value under the maximum reference (represented with the zero and yellow color) is therefore negative and it is represented with the green colors. On the other hand, a non-compliant value over the maximum reference is positive and represented with the red values. The lower the value the farther from the reference value. For example, a value of (0.2) on the primary energy consumption for the scenario $x$, means that the examined indicator exceeds by $20 \%$ the maximum reference value for primary energy consumption. Likewise, a value of $(-0.2)$ indicates that the energy consumption for the scenario $x$ is $20 \%$ below the maximum reference value.

Table 10 shows the results comparison for each alternative by building and country (rows) and the result for compliance/not compliance with the nZEB definition under the scope of the respective assessor country (columns). 
Table 10. Results: compliance of different building constellations with various national nZEB definitions and calculation methodologies.

\begin{tabular}{|c|c|c|c|c|c|c|c|c|c|c|c|}
\hline & \multicolumn{2}{|c|}{ Case } & \multicolumn{2}{|c|}{$\begin{array}{l}\text { nZEB Definition } \\
\text { Austria (AT) }\end{array}$} & \multicolumn{2}{|c|}{$\begin{array}{l}\text { nZEB Definition } \\
\text { Germany (DE) }\end{array}$} & \multicolumn{2}{|c|}{$\begin{array}{l}\text { nZEB Definition } \\
\text { Spain (ES) }\end{array}$} & \multicolumn{2}{|c|}{$\begin{array}{l}\text { nZEB Definition } \\
\text { England (UK) }\end{array}$} & \multirow[t]{2}{*}{$\begin{array}{l}\text { Consistent Assessment } \\
\text { of nZEB Status }\end{array}$} \\
\hline \multirow{9}{*}{ AT } & \multirow{3}{*}{ SFH } & Case 1 & $\mathrm{NO}$ & 0.65 & $\mathrm{NO}$ & 0.64 & $\mathrm{NO}$ & 0.03 & O.K & -0.19 & \\
\hline & & Case 2 & O.K & -0.33 & O.K & -0.05 & O.K & -0.39 & O.K & -0.60 & nZEB \\
\hline & & Case 3 & O.K & -0.18 & O.K & -0.52 & O.K & -0.43 & O.K & -0.54 & nZEB \\
\hline & \multirow{3}{*}{ MFH } & Case 1 & NO & 0.38 & $\mathrm{NO}$ & 0.62 & $\mathrm{NO}$ & 0.02 & O.K & -0.2 & \\
\hline & & Case 2 & O.K & -0.13 & O.K & -0.02 & O.K & -0.16 & O.K & -0.52 & nZEB \\
\hline & & Case 3 & O.K & -0.28 & O.K & -0.25 & O.K & -0.21 & O.K & -0.53 & nZEB \\
\hline & \multirow{3}{*}{$\mathrm{AB}$} & Case 1 & $\mathrm{NO}$ & 0.58 & $\mathrm{NO}$ & 0.60 & O.K & -0.06 & O.K & -0.01 & \\
\hline & & Case 2 & O.K & -0.14 & $\mathrm{NO}$ & 0.10 & $\mathrm{NO}$ & 0.001 & O.K & -0.28 & \\
\hline & & Case 3 & O.K & -0.33 & O.K & -0.23 & O.K & -0.05 & O.K & -0.44 & nZEB \\
\hline \multirow{9}{*}{ DE } & \multirow{3}{*}{ SFH } & Case 1 & O.K & -0.06 & $\mathrm{NO}$ & 0.45 & O.K & -0.34 & O.K & -0.32 & \\
\hline & & Case 2 & O.K & -0.14 & $\mathrm{NO}$ & 0.10 & O.K & -0.22 & O.K & -0.46 & \\
\hline & & Case 3 & O.K & -0.19 & O.K & -0.57 & O.K & -0.01 & O.K & -0.57 & nZEB \\
\hline & \multirow{3}{*}{ MFH } & Case 1 & NO & 1.16 & $\mathrm{NO}$ & 0.75 & O.K & -0.05 & O.K & -0.05 & \\
\hline & & Case 2 & O.K & -0.36 & $\mathrm{NO}$ & 0.40 & $\mathrm{NO}$ & 0.16 & O.K & -0.21 & \\
\hline & & Case 3 & O.K & -0.47 & $\mathrm{NO}$ & 0.47 & $\mathrm{NO}$ & 0.35 & O.K & -0.17 & \\
\hline & \multirow{3}{*}{ AB } & Case 1 & O.K & -0.02 & $\mathrm{NO}$ & 2.20 & $\mathrm{NO}$ & 0.47 & NO & 0.43 & NOT nZEB \\
\hline & & Case 2 & O.K & -0.04 & O.K & -0.10 & O.K & -0.16 & O.K & -0.41 & nZEB \\
\hline & & Case 3 & O.K & -0.04 & O.K & -0.50 & $\mathrm{NO}$ & 0.03 & O.K & -0.45 & \\
\hline \multirow{9}{*}{ ES } & \multirow{3}{*}{ SFH } & Case 1 & O.K & -0.68 & $\mathrm{NO}$ & 0.95 & $\mathrm{NO}$ & 1.08 & $\mathrm{NO}$ & 0.85 & \\
\hline & & Case 2 & O.K & -0.01 & $\mathrm{NO}$ & 0.06 & $\mathrm{NO}$ & 1.13 & $\mathrm{NO}$ & 0.31 & \\
\hline & & Case 3 & O.K & -0.01 & NO & 0.52 & $\mathrm{NO}$ & 1.13 & $\mathrm{NO}$ & 0.74 & \\
\hline & \multirow{3}{*}{ MFH } & Case 1 & O.K & -0.42 & $\mathrm{NO}$ & 1.43 & $\mathrm{NO}$ & 0.97 & $\mathrm{NO}$ & 1.43 & \\
\hline & & Case 2 & O.K & -0.03 & $\mathrm{NO}$ & 0.53 & $\mathrm{NO}$ & 1.26 & $\mathrm{NO}$ & 0.71 & \\
\hline & & Case 3 & O.K & -0.05 & NO & 0.94 & $\mathrm{NO}$ & 1.26 & $\mathrm{NO}$ & 1.09 & \\
\hline & \multirow{3}{*}{$\begin{array}{l}\text { SFH } \\
\text { PHS }\end{array}$} & Case 1 & O.K & -0.09 & $\mathrm{NO}$ & 0.73 & $\mathrm{NO}$ & 0.23 & $\mathrm{NO}$ & 0.15 & \\
\hline & & Case 2 & O.K & -0.51 & $\mathrm{NO}$ & 0.25 & O.K & -0.09 & O.K & -0.16 & \\
\hline & & Case 3 & O.K & -0.45 & $\mathrm{NO}$ & 0.25 & O.K & -0.04 & O.K & -0.34 & \\
\hline \multirow{9}{*}{ UK } & \multirow{3}{*}{ SFH } & Case 1 & O.K & -0.28 & $\mathrm{NO}$ & 0.76 & O.K & -0.36 & $\mathrm{NO}$ & 0.10 & \\
\hline & & Case 2 & O.K & -0.51 & $\mathrm{NO}$ & 0.15 & O.K & -0.38 & O.K & -0.32 & \\
\hline & & Case 3 & O.K & -0.48 & O.K & -0.003 & O.K & -0.38 & O.K & -0.38 & nZEB \\
\hline & \multirow{3}{*}{ MFH } & Case 1 & O.K & -0.30 & $\mathrm{NO}$ & 0.54 & O.K & -0.43 & O.K & -0.09 & \\
\hline & & Case 2 & O.K & -0.43 & NO & 0.10 & O.K & -0.24 & O.K & -0.35 & \\
\hline & & Case 3 & O.K & -0.43 & O.K & -0.11 & O.K & -0.24 & O.K & -0.44 & nZEB \\
\hline & \multirow{3}{*}{$\begin{array}{l}\text { MFH } \\
\text { PHS }\end{array}$} & Case 1 & $\mathrm{NO}$ & 0.65 & $\mathrm{NO}$ & 0.16 & $\mathrm{NO}$ & 1.78 & O.K & -0.28 & \\
\hline & & Case 2 & O.K & -0.33 & O.K & -0.13 & $\mathrm{NO}$ & 2.24 & O.K & -0.39 & \\
\hline & & Case 3 & O.K & -0.18 & O.K & -0.13 & NO & 2.36 & O.K & -0.38 & \\
\hline
\end{tabular}

$\mathrm{SFH}=$ Single family house; $\mathrm{MFH}=$ Multi family house; $\mathrm{AB}=$ Apartment block; $\mathrm{PHS}=$ Passive house .

\section{Conclusions and Discussion}

From the results it is possible to point out the following conclusions:

- Only 9 of the 36 analysed cases have a consistent result of nZEB definition compliance under the scope of all countries. Different climate conditions, energy requirements, primary energy factors, ambition levels, and calculation methodologies lead to the problem of an uneven cross-country comparison. 5 cases do not comply with the Austrian nZEB definition. Nine cases do not comply with the English nZEB definition. 17 cases do not comply with the assumed Spanish nZEB definition and 24 cases do not comply with the planned German nZEB definition.

- The numerical results would indicate that the planned German nZEB definition is the strictest and therefore the most ambitious one, however it is difficult to draw this conclusion, first due to the limitation of the current work, and second because the ambition level derives not exclusively from the numerical targets. In this sense, for example, the Austrian nZEB definition is very flexible considering that there are two alternatives to comply (see Section 1.2.1), but at the same time, Austria is one of the few among the MS with such a detailed definition for new and existing, residential and non-residential buildings plus well-defined intermediate targets, so the progress can be more easily monitored, showing therefore a high ambition level in terms of enforcement and execution. Similarly, the English nZEB/ "zero carbon" definition displays a high ambition level in terms of the timespan since it dates already from 2016 and target for all new domestic 
buildings in England to be "zero carbon". Finally, the Spanish nZEB definition is a clear example of the challenge that supposes a direct nZEB definition comparison among countries with such different climate conditions. A delayed nZEB definition and transposition of the EPBD directive caused among other reasons by the economic context, indicate that there is still room to improve also in terms of ambition levels, but the steps are being taken with the envisaged modification of the Spanish building code DBHE that considers the re-evaluation of the energy indicators and use of renewable energy in buildings (see Section 1.2.3).

- Primary energy consumption might not be the most adequate indicator for a cross-country comparison. Since additional steps from the energy need going through the energy use and the delivered energy involve additional parameters that change from country to country, the comparison becomes less transparent and therefore less meaningful [7,33]. Of course, the intention of setting a national nZEB definition is not first of all a smooth cross-country comparison, but rather the push of energy performance in the building stock. Nevertheless, we believe that a system that allows for cross-country comparison would lead to a higher transparency and in the end could lead to higher energy performance standards.

- The definition of (a) A single EU level absolute maximum value for the energy need for heating and cooling along with a corresponding correction factor depending on the climate zone at the EU level (using a common classification like the Köppen-Geiger climate classification for example) and (b) Relative target values for the primary energy consumption in regard to a reference building instead of fixed maximum values, might contribute to a most equitable cross-country building energy performance comparison since the impact of the local and boundary conditions and the impact of additional parameters introduced along the calculation from energy need over energy use and delivered energy up to primary energy are diminished. This last action could be seen as only a shift of the burden from the assessed building to the reference building, but reference building provisions can be more easily compared at the EU level by means of directives, such as the eco-design directive 2009/125/EC [34].

- The eco-design directive 2009/125/EC provides a framework for establishing requirements for "energy-related" products placed on the EU market. Current requirements cover only "energy-using" products, such as boilers, air conditioners, and ventilation units. The future inclusion of products as windows and insulation materials might help to harmonize the EU Member states ambition levels by building renovations towards goals beyond the 2020 horizon.

- The further development of nZEB definitions and the setting of energy performance requirements in buildings can be improved through the lessons learned from the already in place nZEB buildings. Although it is shown that the climate condition is one of the main parameters that makes a direct comparison of nZEB definitions among EU countries very difficult, an interesting outcome from a recent analysis [35] based on a sample of 411 representative European high energy performance buildings (new and renovated, residential, and non-residential) mainly located in mild-cold climates, whose features have been collected within the EU IEE ZEBRA2020 project, deduce that the climate conditions do not represent the main parameter affecting the definition of the technology package to achieve the nZEB target. In other words, the energy efficiency technological solutions are selected independently to the climate condition. In the same analysis, the use of mechanical ventilation as a recurrent technical solution in new and renovated nZEBs with a share of $89 \%$ of the sample and a high penetration of heat recovery systems is evidenced. It is also shown that heat pump systems are the most used technology in heating systems to achieve nZEB targets. From the comparison with our results we can conclude that the practical implementation of high-performance buildings according to [26], differs from the (expected) implementation of nZEB building codes.

Author Contributions: All authors contributed to this research. The analysis and the writing of this paper were carried out by J.F.G. L.K. supported the data analysis and supervised the paper. 
Funding: This research received no external funding.

Conflicts of Interest: The authors declare no conflict of interest.

\section{References}

1. European Commission. Proposal for a Directive of the European Parliament and of the Council Amending Directive 2010/31/EU on the Energy Performance of Buildings, 2017/0381 (COD); European Commission: Brussels, Belgium, 2016.

2. Directive 2010/31/EU of the European Parliament and of the Council of 19 May 2010 on the Energy Performance of Buildings (Recast 2010) OJ L 153, 18.6.2010. pp. 13-35. Available online: http:/ / eur-lex. europa.eu/eli/dir/2010/31/oj (accessed on 13 February 2017).

3. Ahmed, K.; Carlier, M.; Feldmann, C.; Kurnitski, J. A New Method for Contrasting Energy Performance and Near-Zero Energy Building Requirements in Different Climates and Countries. Energies 2018, 11, 1334. [CrossRef]

4. IEE Project EPISCOPE/ TABULA. Available online: http://webtool.building-typology.eu/\#bm (accessed on 13 February 2017).

5. Passivhaus-Projekt. Passivhaus-Datenbank. Available online: http://www.passivhausprojekte.de (accessed on 13 February 2017).

6. Erhorn, H.; Erhorn-Kluttig, H. Terms and definitions for high performance buildings. In Detailed Report for the Concerted Action, Energy Performance of Buildings; European Union: Brussels, Belgium, 2011.

7. Concerted Action, Energy Performance of Buildings. 2016 Implementing the Energy Performance of Buildings Directive; Concerted Action; Energy Performance of Buildings: Lisbon, Portugal, 2015; ISBN 978-972-8646-32-5.

8. Directive 2009/28/EC. European Parliament and Council. On the Promotion of the Use of Energy from Renewable Sources and Amending and Subsequently Repealing Directives 2001/77/EC and 2003/30/EC. Available online: https: / / eur-lex.europa.eu/legal-content/EN/ALL/?uri=celex:32009L0028 (accessed on 13 February 2017).

9. Sartori, I.; Napolitano, A.; Voss, K. Net zero energy buildings: A consistent definition framework. Energy Build. 2012, 48, 220-232. [CrossRef]

10. Kurnitski, J.; Allard, F.; Braham, D.; Goeders, G.; Heiselberg, P.; Jagemar, L.; Kosonen, R.; Lebrun, J.; Mazzarella, L.; Railio, J.; et al. How to Define Nearly Net Zero Energy Buildings nZEB—REHVA Proposal for Uniformed National Implementation of EPBD Recast. 2011. Available online: http:/ / www.rehva.eu/ fileadmin/hvac-dictio/03-2011/How_to_define_nearly_net_zero_energy_buildings_nZEB.pdf (accessed on 6 March 2017).

11. REHVA nZEB Technical Definition and System Boundaries for Nearly Zero Energy Buildings, 2013 Revision for Uniformed National Implementation of EPBD Recast Prepared in Cooperation with European Standardization Organization CEN; Report No 4; REHVA, Federation of European Heating, Ventilation and Air-Conditioning Associations: Brussels, Belgium, 2013.

12. Toleikyte, A.; Kranzl, L.; Bointner, R.; Bean, F.; Cipriano, J.; De Groote, M.; Hermelink, A.; Klinski, M.; Kretschmer, D.; Lapillone, B.; et al. Strategies for a Nearly Zero-Energy Building Market Transition in the European Union. Final Report of the Project ZEBRA2020. 2016. Available online: https:/ /www.zebra2020.eu/ website/wp-content/uploads/2014/08/ZEBRA2020_Strategies-for-nZEB_07_LQ_single-pages-1.pdf (accessed on 13 February 2017).

13. Lichtmess, M. Vereinfachungen für die Energetische Bewertung von Gebäuden. Ph.D. Thesis, 2010. Available online: http:/ / www.enob.info/de/publikationen/publikation/details/vereinfachungen-fuerdie-energetische-bewertung-von-gebaeuden/ (accessed on 6 March 2017).

14. Gustafsson, M.; Thygesen, R.; Karlsson, B.; Ödlund, L. Rev-Changes in Primary Energy Use and $\mathrm{CO}_{2}$ Emissions-An Impact Assessment for a Building with Focus on the Swedish Proposal for Nearly Zero Energy Buildings. Energies 2017, 10, 978. [CrossRef]

15. Touloupaki, E.; Theodosiou, T. Optimization of External Envelope Insulation Thickness: A Parametric Study. Energies 2017, 10, 270. [CrossRef]

16. Rey-Hernández, J.M.; Velasco-Gómez, E.; San José-Alonso, J.F.; Tejero-González, A.; Rey-Martínez, F.J. Energy Analysis at a Near Zero Energy Building. A Case-Study in Spain. Energies 2018, 11, 857. [CrossRef] 
17. Hachem-Vermette, C.; Guarino, F.; La Rocca, V.; Cellura, M. Towards achieving net-zero energy communities: Investigation of design strategies and seasonal solar collection and storage net-zero. Sol. Energy 2018. [CrossRef]

18. Cellura, M.; Ciulla, G.; Guarino, F.; Longo, S. Redesign of a Rural Building in a Heritage Site in Italy: Towards the Net Zero Energy Target. Buildings 2017, 7, 68. [CrossRef]

19. Zeiler, W.; Gvozdenović, K.; de Bont, K.; Maassen, W. Toward cost-effective nearly zero energy buildings: The Dutch Situation. Sci. Technol. Built Environ. 2016, 22, 911-927. [CrossRef]

20. Attia, S.; Eleftheriou, P.; Xeni, F.; Morlot, R.; Ménézo, C.; Kostopoulos, V.; Betsi, M.; Kalaitzoglou, I.; Pagliano, L.; Cellura, M. Overview and future challenges of nearly zero energy buildings (nZEB) design in Southern Europe. Energy Build. 2017, 155, 439-458. [CrossRef]

21. Guarino, F.; Tumminia, G.; Longo, S.; Mistretta, M.; Bilotta, R.; Cellura, M. Energy planning methodology of net zero energy solar neighborhoods in the Mediterranean basin. Sci. Technol. Built Environ. 2016, 22, 928-938. [CrossRef]

22. D'Agostino, D.; Zangheri, P.; Castellazzi, L. Towards Nearly Zero Energy Buildings in Europe: A Focus on Retrofit in Non-Residential Buildings. Energies 2017, 10, 117. [CrossRef]

23. Al-Saeed, Y.W.; Ahmed, A. Evaluating Design Strategies for Nearly Zero Energy Buildings in the Middle East and North Africa Regions. Designs 2018, 2, 35. [CrossRef]

24. Hermelink, A.; Schimschar, S.; Boermans, T.; Pagliano, L.; Zangheri, P.; Armani, R.; Voss, K.; Musall, E. Towards nZEB under the EPBD—Definition of Common Principles under the EPBD. Final Report. February 2013. Available online: https:/ / ec.europa.eu/energy/sites/ener/files/documents/nzeb_full_ report.pdf (accessed on 20 January 2017).

25. OIB. OIB-Richtlinie 6: Energieeinsparung und Wärmeschutz; OIB-330.6-009/15; Österreichisches Institut für Bautechnik: Vienna, Austria, 2015.

26. OIB. OIB-Richtlinie 6: Energieeinsparung und Wärmeschutz; OIB-330.6-094/11; Österreichisches Institut für Bautechnik: Vienna, Austria, 2011.

27. OIB. Dokument zur Definition des Niedrigstenergiegebäudes und zur Festlegung von Zwischenzielen in einem, Nationalen Plan' gemäß Artikel 9 (3) zu 2010/31/EU; OIB-330.6-002/13; Österreichisches Institut für Bautechnik: Vienna, Austria, 2012.

28. Ministerio de Fomento, Secretaría de Estado de Infraestructuras, Transporte y Vivienda. Dirección General de Arquitectura, Vivienda y Suelo. Documento Descriptivo Climas de Referencia. February 2017. Available online: http:/ / www.codigotecnico.org/images/stories/pdf/ahorroEnergia/20170202-DOC-DB-HE-0-Climas\% 20de\%20referencia.pdf (accessed on 3 March 2017).

29. Domestic Building Services Compliance Guide. Available online: https://www.gov.uk/government/ uploads/system/uploads/attachment_data/file/453968/domestic_building_services_compliance_guide. pdf (accessed on 3 March 2017).

30. Enercalc Excel Based Tool. Available online: http:/ / www.enec.de/styled-3/index.html (accessed on 6 March 2017).

31. Nullenergiegebäude als Gebäude Realität. EnOB: Forschung für Energieoptimiertes Bauen. Available online: http:/ / www.enob.info/de/nullenergie-plusenergie-klimaneutrale-gebaeude-im-stromnetz-20/ nullenergiegebaeude-als-gebaute-realitaet/ (accessed on 8 March 2017).

32. ÖNORM B 8110-5:2011, Austria Standards Institute, Issue: 2011-03-01. Thermal Insulation in Buildings. Part 5: Model of Climate and User Profiles; Austria Standards Institute: Vienna, Austria, 2011.

33. ZEBRA 2020-NEARLY ZERO-ENERGY BUILDING STRATEGY 2020 Deliverable D2.1: Definition of Nearly Zero Energy Buildings as Used for Market Tracking. September 2014. Available online: https://www. zebra2020.eu/website/wp-content/uploads/2014/08/ZEBRA2020-Deliverable-D21_final.pdf (accessed on 13 February 2017).

34. Directive 2009/125/EC. A Framework for the Setting of Ecodesign Requirements for Energy-Related Products; European Union: Brussels, Belgium, 2009.

35. Paoletti, G.; Pascual Pascuas, R.; Pernetti, R.; Lollini, R. Nearly Zero Energy Buildings: An Overview of the Main Construction Features across Europe. Buildings 2017, 7, 43. [CrossRef]

(C) 2018 by the authors. Licensee MDPI, Basel, Switzerland. This article is an open access article distributed under the terms and conditions of the Creative Commons Attribution (CC BY) license (http:/ / creativecommons.org/licenses/by/4.0/). 